\title{
Intra-Household and Inter-Personal Comparisons of Subjective Well-Being: Dorrit Posel
}

\section{Dorrit Posel ${ }^{1}$}

Published online: 8 October 2021

(C) The International Society for Quality-of-Life Studies (ISQOLS) and Springer Nature B.V. 2021

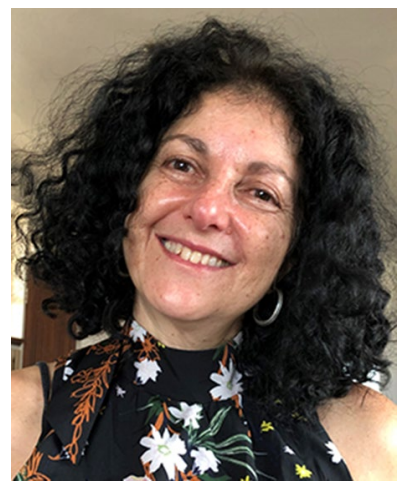

I came to study economics almost by accident, looking for a "filler" course in a Bachelor of Science programme, and was immediately drawn to how it combined the rigour of mathematics with a study of people and social relations. I completed my Honours and Master's degrees in economics at the former University of Natal, Durban (UND, now University of KwaZulu-Natal) in South Africa, a $\mathrm{PhD}$ at the University of Massachusetts, Amherst, and a post-doctoral fellowship at the University of Princeton. In returning to South Africa in 2000, I re-joined the economics programme at UND. In 2005, I received the Vice-Chancellor's Research Award, and in 2007, I moved to the (then) School of Development Studies after being awarded a South African Research Chair in Economic Development. In 2016, I moved to the University of the Witwatersrand, in Johannesburg, as a distinguished professor and to take up the Helen Suzman Chair in Political Economy.

Dorrit Posel

Dorrit.Posel@wits.ac.za

1 School of Economics and Finance, University of the Witwatersrand, 1 Jan Smuts Ave, Braamfontein, Johannesburg 2000, South Africa 
My interest in subjective indicators of the quality of life developed through my research on the economics of gender. This is because subjective measures offered three distinct advantages over money-metric indicators of well-being in the household. First, in contrast to money-metric measures, which are difficult to allocate across household members who are earners and dependents, subjective indicators of well-being are individually ascribed and hence offer a unique empirical window into intra-household differences in the quality of life. Second, subjective measures are typically positively and significantly correlated with money-metric indicators, but they are also independently correlated with other aspects of well-being, including physical and mental health, time poverty and the quality of inter-personal relations. Third, people are frequently unwilling to provide information about how much income they earn. In contrast, questions that ask people about their individual wellbeing - how satisfied they are with life, for example - are far less prone to nonreports. Even questions that ask people to assess their economic status relative to others or to a series of benchmarks, are more likely to be answered than questions that ask people to divulge how much income they earn.

As a student of economics during the 1980s in South Africa, I did not receive instruction in empirical research methods. This was partly because of the influence of Marxist scholarship at the time, which eschewed quantitative analysis, and because the limited empirical data that were collected, for example, in the population censuses, were viewed as neither credible nor legitimate (Posel, 2017). However, this changed in 1993, when the first nationally representative household survey for South Africa was undertaken, primarily to measure poverty and living standards at the start of the country's democratic transition.

During the mid-to-late 1990s, when I was a doctoral student at the University of Massachusetts, this survey (the Project for Living Standards and Development, or PSLSD) started to be probed, but largely by academics based outside South Africa. In my doctoral thesis, I analysed the PSLSD data to explore "circular" or temporary labour migration and remittance behaviour in South Africa. Because circular migrants typically retain membership in their household of origin, an exploration of who migrates, who remits, to whom and how much, offered a unique empirical window into intra-household labour allocations and intra-family private transfers (see e.g. Posel, 2001; Bowles \& Posel, 2005).

In its scope, coverage and conception of the household, the PSLSD was an innovative survey. It was also the first nationally representative household survey in South Africa to include questions on subjective well-being. Unfortunately, a question on life satisfaction asked respondents to report on "household satisfaction"; but the PSLSD was the first of many, and subsequent surveys have collected information about individual life satisfaction and subjective reports of economic status, giving rise to a growing literature on subjective well-being in South Africa.

In my own research, I have used subjective measures to describe differences in the life satisfaction of men and women in co-resident unions, and to show how, in a developing country context, the absence of basic services such as piped water, reduces women's relative life satisfaction (Posel \& Casale, 2015). I have also shown that there are large differences in subjective and money-metric indicators of economic status and position. For example, people consistently underestimate their 
economic status relative to others, and perceptions of economic ranking are far stronger predictors of people's life satisfaction than actual economic rankings (see e.g. Posel \& Casale, 2011). Relative comparisons with others who are perceived as more successful also stimulate income aspirations, and particularly if others in the same group are upwardly mobile (Posel \& Rogan, 2019).

However, my research has shown further that most people are less likely to assess their status as poor than to be measured as income poor, and particularly when they live in larger households (Posel \& Rogan, 2016). Solo-dwellers, in contrast, are far more likely to think that they are poor than to be identified as income poor. These divergences between subjective and money-metric poverty rates speak to the importance of economies of scale in the household, particularly in contexts where resources are scarce, which are ignored in per capita money-metric poverty calculations, and they moderate the commonly found positive association between household size and poverty. My current research further explores the implications of solo-living and extrahousehold links and support systems for people's well-being and their quality of life.

Despite their advantages, I also have uncovered limitations to subjective measures, for example, as retrospective indicators of childhood socio-economic status (von Fintel \& Posel, 2016). Evidence that subjective recall of past conditions is "anchored" by current circumstances means that these recall measures are not good substitutes for longitudinal data.

With persistently high rates of inequality, poverty and unemployment, and very low rates of marriage, working in and on South Africa has provided a paradoxically rich environment in which to be an economist who researches intra-household and interpersonal comparisons of well-being.

\section{References}

Bowles, S., \& Posel, D. (2005). Genetic relatedness predicts South African migrant workers' remittances to their families. Nature, 434, 380-383.

Posel, D. (2001). Intra-family transfers and income-pooling: A study of remittances in Kwazulu-Natal. South African Journal of Economics, 69(3), 501-528.

Posel, D. (2017). Enriching Economics in South Africa: Interdisciplinary collaboration and the value of quantitative-qualitative exchanges. Journal of Economic Methodology, 24(2), 119-133.

Posel, D., \& Casale, D. (2011). Relative standing and subjective well-being in South Africa: The role of perceptions, expectations and income mobility. Social Indicators Research, 104(2), 195-223.

Posel, D., \& Casale, D. (2015). Differences in subjective well-being within households. An analysis of married and cohabiting couples in South Africa. African Review of Economics and Finance, 7(1), 32-52.

Posel, D., \& Rogan, M. (2016). Measured as poor versus feeling poor: Comparing money-metric and subjective poverty rates in South Africa. Journal of Human Development and Capabilities, 17(1), 55-73.

Posel, D., \& Rogan, M. (2019). Inequality, social comparisons and minimum income aspirations: Evidence from a highly unequal country. Journal of Human Development and Capabilities, 20(1), 94-111.

von Fintel, D., \& Posel, D. (2016). Errors in recalling childhood socio-economic status: The role of anchoring and household formation. Social Indicators Research, 126(1), 119-140.

Publisher's Note Springer Nature remains neutral with regard to jurisdictional claims in published maps and institutional affiliations. 